www.jmscr.igmpublication.org

Impact Factor 5.84

Index Copernicus Value: 83.27

ISSN (e)-2347-176x ISSN (p) 2455-0450

crossref DOI: https://dx.doi.org/10.18535/jmscr/v5i1.92

\author{
Journal Of Medical Science And Clinical Research \\ IGM Publication \\ An official Publication of IGM Publication
}

\title{
Open Versus Laparoscopic Appendicectomy- A Comparative Study
}

\author{
Authors \\ Dr Tanmay Mehta, Dr H.V. Nerlekar
}

\begin{abstract} respect to:

- Duration of procedure.

- Post operative pain.

- Duration of analgesic use.

- Complication encountered

- Post operative length of hospital stay.

- Conversion to open appendectomy
\end{abstract}

Background: Laparoscopic appendicectomy has rapidly become established as the popular alternative to open appendicectomy, it has a safety profile better than open procedure.

Objectives: Laparoscopic procedure for appendicectomy is compared with open surgical technique with

Methods: Prospective study from December 2008 to May 2010, involved 50 patients with diagnosis of acute or recurrent appendicitis was entered into a study randomizing the choice of operation to either the open or the laparoscopic technique. Statistical comparisons were performed using the chi-square test and students ' $t$ ' test.

Results: 25 patients were assigned to the laparoscopic appendicectomy group and 25 patients were assigned to the open appendicectomy group. There were statistically significant difference noted in respect to postoperative pain (LA, $1.21 \pm 0.63 \mathrm{Vs} . \mathrm{OA}, 2.72 \pm 0.87: \mathrm{P}<0.001)$ duration of analgesic used $(\mathrm{LA}, 2.2 \pm 1.08 \mathrm{Vs}$. OA, $6.44 \pm 1.84: P<0.001)$ postoperative complications like vomiting [LA, $2(8 \%)$ Vs. O.A, 7 (28\%), fever [LA, 1 (4\%) Vs. OA, 4 (16\%), wound infection [LA, 1 (4\% Vs. OA, 5 (20\%), ileus (LA, $17.3 \pm 7.1$ Vs. OA, 30.8 $\pm 8.9: P<0.001)$ postoperative length of hospital stay $(L A, 2.8 \pm 1.23 \mathrm{Vs} . O A, 7.7 \pm 1.95: P<0.001)$ and return to normal work (LA,13.5 $\pm 2.86 \mathrm{Vs.OA}, 20.8 \pm 3.21: P<0.01)$. Although above mentioned advantage were at the cost of slightly increased duration of surgery (LA,71.2 \pm 19.23 Vs.OA,53.8 $\pm 20.04: P<0.01)$.

Conclusions: The patients who underwent laparoscopic appendicectomy had less postoperative pain and shorter duration of analgesic use, less postoperative complications like vomiting, fever ileus and wound infection with shorter postoperative duration of hospital stay and return to normal work when compared with patients who underwent open appendicectomy. Laparoscopic appendicectomy is better than open appendicectomy in selected patients with acute or recurrent appendicitis.

Keywords: Appendicectomy, Laparoscopic appendicectomy, Open appendicectomy, Acute appendicitis.

\section{Introduction}

It is a well-known adage that abdomen is a temple of surprises and a magic box as well. Since the abdomen accommodates innumerable viscera and other anatomical compliments, diseases of the abdomen constitute a topic full of clinical curiosity. A meticulous examination of abdomen is one of the most rewarding diagnostic 
procedures available to the doctor, especially the surgeon and plans an ideal treatment. As had been said by Bailey "A correct diagnosis is the hand maiden of successful operation". Despite the advancements in the fields of diagnosis the surprises never cease. ${ }^{1}$

Acute appendicitis is one of the commonest causes of acute abdomen encountered in surgical practice, requiring emergency surgery. ${ }^{2}$ The life time rate of appendicectomy is $12 \%$ for men and $25 \%$ in women, with approximately $7 \%$ of all people undergoing appendicectomy for acute appendicitis during their lifetime. It has been observed that males had higher rates of appendicitis than females for all age groups with an overall ratio of 1.2 to $1.3: 1 .^{3}$

Even though modern diagnostic facilities, surgical skills, antibiotic therapy have brought down the mortality from $50 \%$ (before 1925) to less than $1 / 1,00,000$ persons, still the morbidity is around 5$8 \%$ mainly due to delayed diagnosis \& treatment, with the resultant complications. ${ }^{4}$

In acute appendicitis however, a treatment delay of even a few hours may result in stormy complication.

It has been said that nothing can be so simple nor yet so difficult as the diagnosis of acute appendicitis.

With the introduction of the laparoscopic technique it provided an opportunity to explore new method of therapy in the management of the suspected cases of the acute appendicitis. ${ }^{5}$

Laparoscopic appendicectomy combines the advantages of diagnosis and treatment in one procedure with the least morbidity ${ }^{6}$. Patients are likely to have less post operative pain and to be discharged from hospital and return to activities of daily living sooner than those who have undergone an open appendicectomy. ${ }^{7}$

Other advantages include decreased wound infection, better cosmetic, ability to explore the entire peritoneal cavity for diagnosis of other conditions and effective peritoneal toileting without the need for extending the incision. ${ }^{4}$
Laparoscopic appendicectomy is increasingly being employed particularly in young women of child bearing age in whom the differential diagnosis of right lower quadrant pain is extensive including gynecologic pathology. ${ }^{8}$

Critics of laparoscopic appendicectomy often point to the increased cost of the surgical equipments as a major disadvantage of the laparoscopic procedure. Despite these concerns however the cost effectiveness for the laparoscopic appendicectomy is easily realized once the decreased hospital stay and entire patient covalence period are accounted for.

The modern era of laparoscopic surgery has evoked remarkable changes in the approach to surgical diseases. The trend towards minimally invasive surgery has prompted general surgeons to scrutinize nearly all surgical procedures for possibility of conversion to the laparoscopic technique. ${ }^{9}$

\section{Aims and Objectives}

The aim of the study is to compare open appendicectomy and laparoscopic appendicectomy with respect to:

1. Duration of the procedure.

2. Post operative pain.

3. Duration of analgesic used.

4. Complication encountered.

5. Post operative length of hospital stay.

6. Conversion to open appendicectomy.

\section{Materials and Methods Source of Data}

The study subject consists of the patients admitted in the surgical wards of all units Krishna Institute of Medical Sciences, Karad with a clinical diagnosis of acute or recurrent appendicitis from Oct 2014 to June 2016 (including sampling procedures, if any).

\section{Method of collection of data:}

This prospective study from Oct 2014 to June 2016 involved 50 cases that were consecutively selected, where the investigator was a part of the 
surgical team managing the patients, by using random sampling technique.

\section{Inclusion Criteria}

All adult patients diagnosed with acute/chronic appendicitis concluded by clinical evaluation and confirmed by USG of abdomen requiring operative intervention are included in this study, after obtaining the consent to be included in the study.

\section{Exclusion Criteria}

1. Patients with associated gynecological disease

2. Patient age less than 12 years

3. Appendicular abscess

Open appendicectomy was performed either under general anesthesia or spinal anesthesia, through a muscle splitting incision in the right iliac fossa. The base of the appendix was crushed and ligated and the stump of the appendix was not invigilated. Laparoscopic technique performed under general anesthesia using a standardized approach involving the open technique for the trocar insertion and by 3-port technique. The appendix was divided after double ligation of the base. Appendix extraction was performed using trocar sleeve to protect the wound from contamination during removal.
All cases were followed in the postoperative period till they were discharged and then later followed for a period of 4 weeks in the out patient department.

The following parameters were observed between the two procedures.

1. Duration of procedure

2. Postoperative pain using a visual analogue pain scale from 0 to 4 .

3. Duration of analgesic used in number of days.

4. Postoperative complications like nausea/vomiting, ileus, fever and wound infection.

5. Post operative length of hospital stay in number of days was noted.

6. Conversion to open appendicectomy.

A proforma was used to collect the relevant information. Data was analyzed using the Students $\mathrm{t}$-test, Chi-square analysis and $\mathrm{P}$ value of $<0.05$ was considered significant.

\section{Results}

\section{Patients Demographics}

The results of the analysis of data on 25 patients who underwent open appendicectomy and another group of 25 patients, who were operated laparoscopic ally are as follows:

Table -1: Age and Sex Distribution

\begin{tabular}{|c|c|c|c|c|c|}
\hline \multirow{3}{*}{ Characteristic } & \multicolumn{4}{|c|}{ Appendicectomy } & \multirow{3}{*}{ Total } \\
\hline & \multicolumn{2}{|c|}{ Open } & \multicolumn{2}{|c|}{ Laparoscopy } & \\
\hline & $\mathrm{N}$ & $\%$ & $\mathrm{~N}$ & $\%$ & \\
\hline Patients analyzed & 25 & 100 & 25 & 100 & 50 \\
\hline \multicolumn{6}{|l|}{ SEX } \\
\hline Male & 13 & 52 & 8 & 32 & \\
\hline Female & 12 & 48 & 17 & 68 & \\
\hline \multicolumn{6}{|l|}{ Age (years) } \\
\hline $10-20$ & 7 & 28 & 10 & 40 & \\
\hline $21-30$ & 10 & 40 & 10 & 40 & \\
\hline $31-40$ & 4 & 16 & 3 & 12 & \\
\hline $41-50$ & 4 & 16 & 2 & 8 & \\
\hline Mean age \pm SD & \multicolumn{2}{|c|}{$27.2 \pm 5.62$} & \multicolumn{2}{|c|}{$25.52 \pm 7.81$} & \\
\hline
\end{tabular}

In present study $13(52 \%)$ patients of open appendicectomy and $8(32 \%)$ patients of laparoscopic appendicectomy were males.12 The mean age of the patients in open and laparoscopic appendicectomy was 27.2 and 25.5 years respectively. 


\section{JMSCR Vol||05||Issue||01||Page 15795-15808||January}

Figure-29: Sex distribution

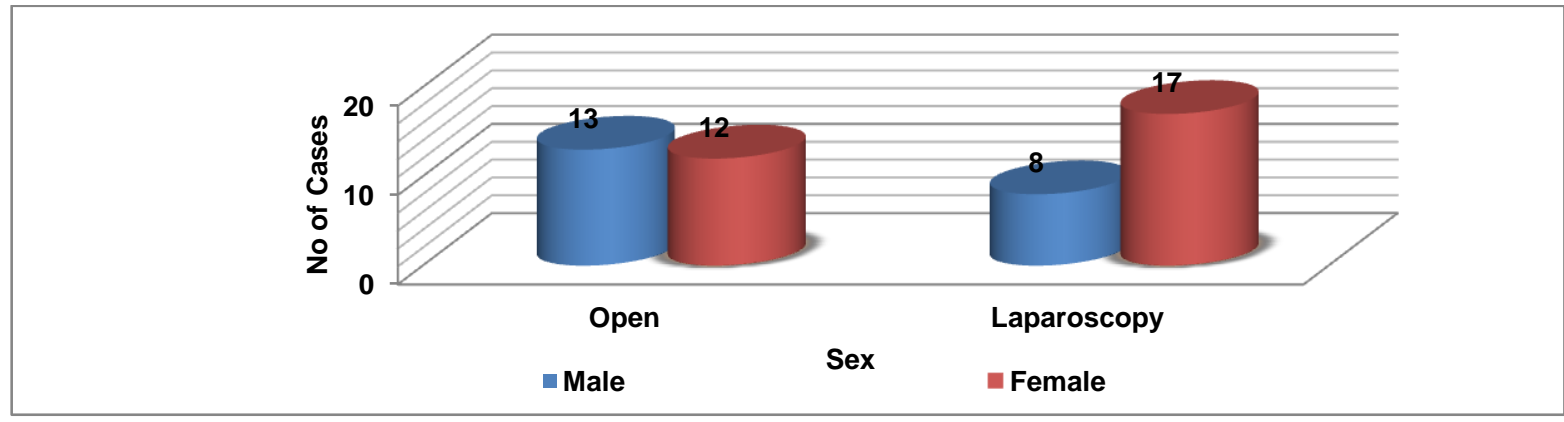

Figure - 30: Age distribution

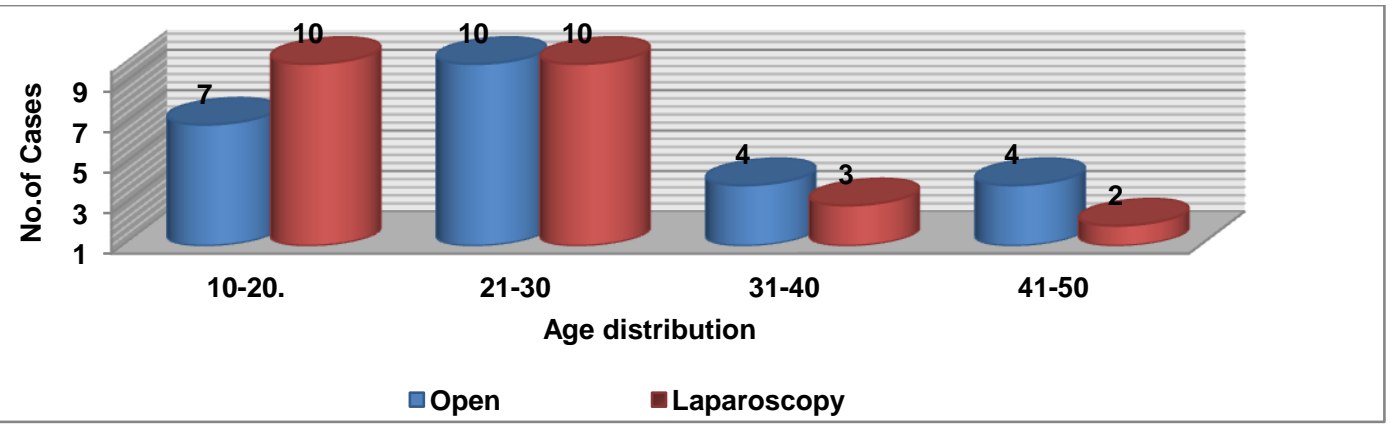

Table -2: Presenting Complaints

\begin{tabular}{|l|c|c|c|c|}
\hline \multirow{2}{*}{ Symptoms } & \multicolumn{4}{|c|}{ Appendicectomy } \\
\cline { 2 - 5 } & \multicolumn{3}{|c|}{ Open } & \multicolumn{2}{|c|}{ Laparoscopy } \\
\cline { 2 - 5 } & $\mathrm{N}$ & $\%$ & $\mathrm{~N}$ & $\%$ \\
\hline Abdominal Pain & 25 & 100 & 25 & 100 \\
\hline Nausea/ Vomiting & 16 & 64 & 20 & 80 \\
\hline Fever & 7 & 28 & 5 & 20 \\
\hline
\end{tabular}

Figure -31: Presenting Complaints

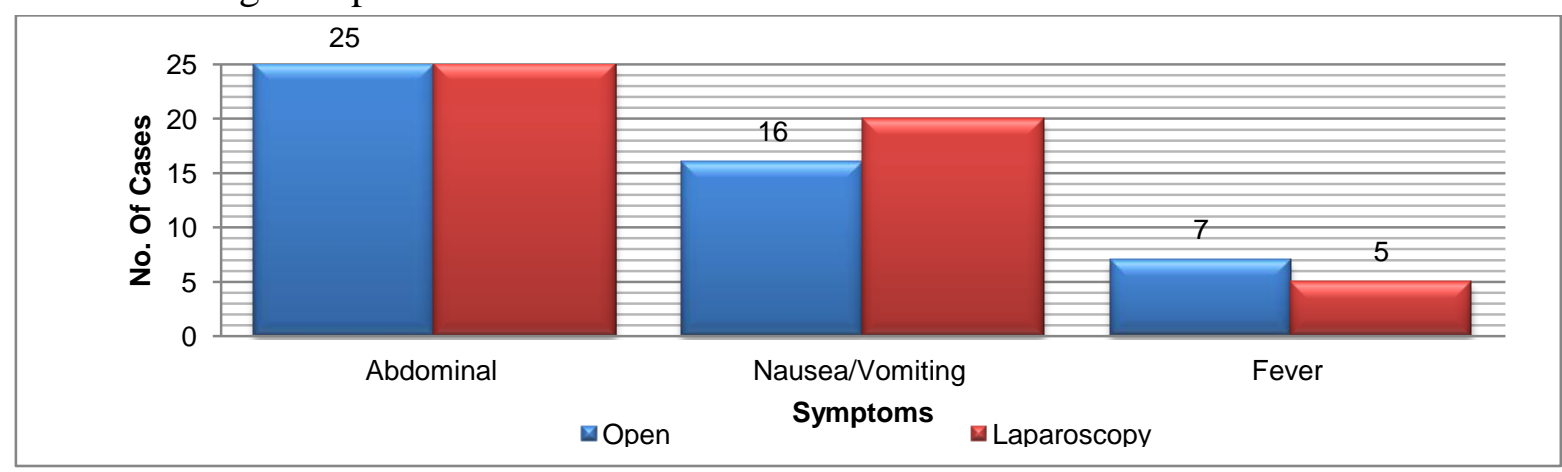

Table -3: Past History

\begin{tabular}{|l|c|c|c|c|}
\hline \multirow{2}{*}{ History of } & \multicolumn{4}{|c|}{ Appendicectomy } \\
\cline { 2 - 5 } & \multicolumn{3}{|c|}{ Open } & \multicolumn{3}{c|}{ Laparoscopy } \\
\cline { 2 - 5 } & $\mathrm{N}$ & $\%$ & $\mathrm{~N}$ & $\%$ \\
\hline Episode of Pain & 10 & 40 & 8 & 32 \\
\hline
\end{tabular}

In present study $10(40 \%)$ and $8(32 \%)$ of the patient of open and laparoscopic group respectively had the history of episodes of abdominal pain in the past. 
Figure-32: Episode of pain

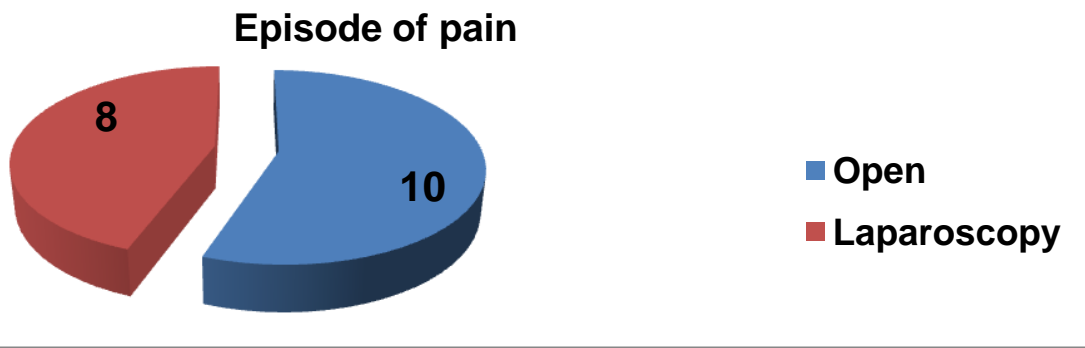

Table- 4: Local Examination

\begin{tabular}{|c|c|c|c|c|}
\hline \multirow{3}{*}{ Findings } & \multicolumn{4}{|c|}{ Appendicectomy } \\
\hline & \multicolumn{2}{|c|}{ Open } & \multicolumn{2}{|c|}{ Laparoscopy } \\
\hline & $\mathrm{N}$ & $\%$ & $\mathrm{~N}$ & $\%$ \\
\hline \multicolumn{5}{|c|}{ Tenderness } \\
\hline Present & 25 & 100 & 25 & 100 \\
\hline Absent & 0 & 0 & 0 & 0 \\
\hline \multicolumn{5}{|c|}{ Guarding/Rigidity } \\
\hline Present & 6 & 24 & 4 & 16 \\
\hline Absent & 19 & 76 & 21 & 84 \\
\hline
\end{tabular}

In present study, all patients in both groups had right iliac fossa tenderness and 6(24\%) patients in open and $4(16 \%)$ patients in laparoscopic group had guarding/rigidity.

Figure -33: Local Examination

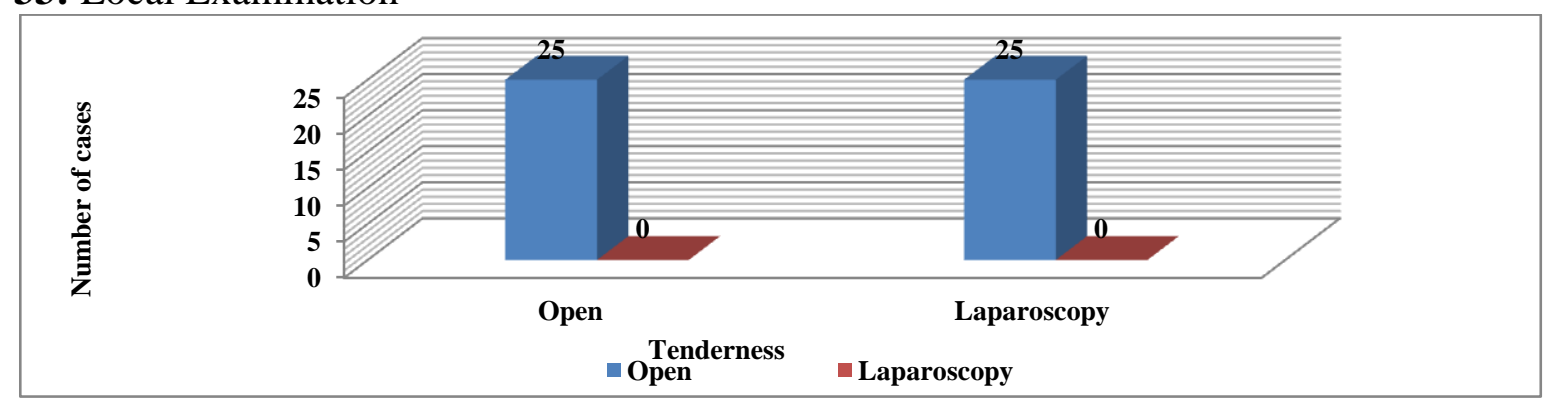

Figure -34: Local Examination

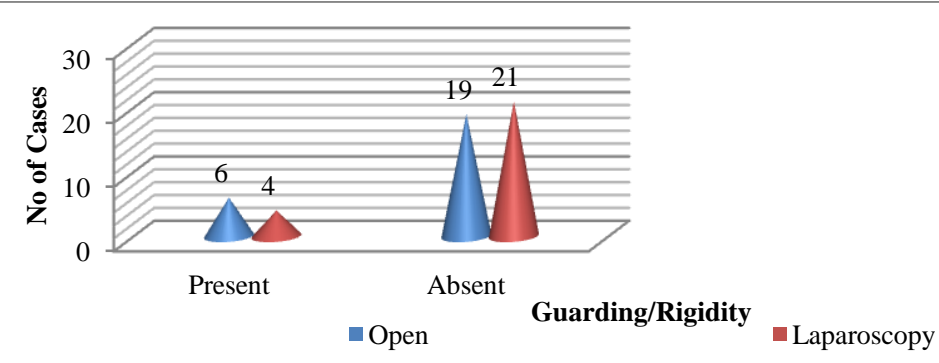

Table -5: Laboratory parameters

\begin{tabular}{|c|c|c|c|c|}
\hline \multirow{3}{*}{ Parameters } & \multicolumn{4}{|c|}{ Appendicectomy } \\
\hline & \multicolumn{2}{|c|}{ Open } & \multicolumn{2}{|c|}{ Laparoscopy } \\
\hline & $\mathrm{N}$ & $\%$ & $\mathrm{~N}$ & $\%$ \\
\hline \multicolumn{5}{|l|}{ Total count } \\
\hline Mean SD & \multicolumn{2}{|c|}{$10.200 \pm 1988.37$} & \multicolumn{2}{|c|}{$10.000 \pm 2067.65$} \\
\hline \multicolumn{5}{|c|}{ Differential count with shift to left } \\
\hline & $\mathrm{N}$ & $\%$ & $\mathrm{~N}$ & $\%$ \\
\hline Present & 20 & 80 & 18 & 72 \\
\hline Absent & 5 & 20 & 7 & 28 \\
\hline
\end{tabular}




\section{JMSCR Vol||05||Issue||01||Page 15795-15808||January}

In present study, the laboratory parameters of patients in open and laparoscopic group were comparable. $20(80 \%)$ and $18(72 \%)$ of open and laparoscopic group respectively were showing were showing differential count with shift to the left.

Figure - 35: Laboratory parameters

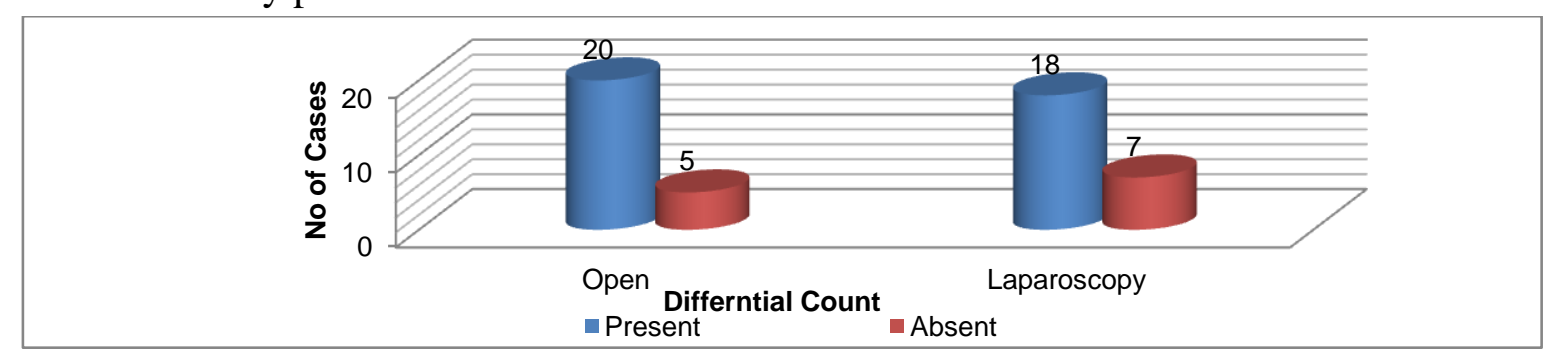

Table -6: Ultrasound Findings

\begin{tabular}{|l|c|c|c|c|}
\hline \multirow{2}{*}{ Report } & \multicolumn{4}{|c|}{ Appendicectomy } \\
\cline { 2 - 5 } & \multicolumn{3}{|c|}{ Open } & \multicolumn{2}{c|}{ Laparoscopy } \\
\cline { 2 - 5 } & $\mathrm{N}$ & $\%$ & $\mathrm{~N}$ & $\%$ \\
\hline Normal & 5 & 20 & 7 & 28 \\
\hline Abnormal & 20 & 80 & 18 & 72 \\
\hline
\end{tabular}

In present study, abnormal pathology was noted in $20(80 \%)$ and $18(72 \%)$ of open and laparoscopic groups respectively. Ultrasound was normal in 5

(20\%) and $7(28 \%)$ of open and laparoscopic groups respectively.

Figure-36: Ultrasound Findings

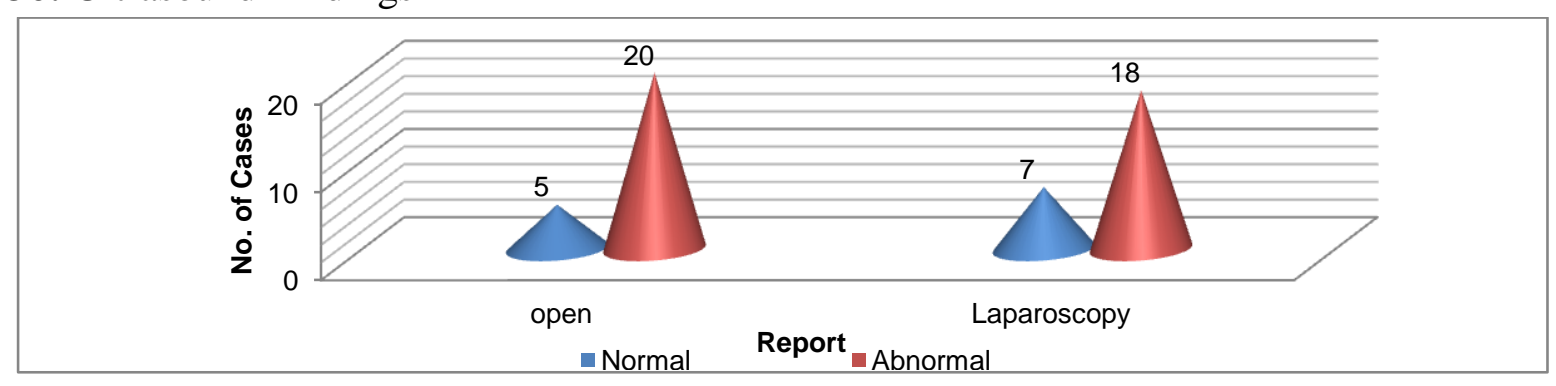

Table-7: Duration of the surgery

\begin{tabular}{|l|c|c|c|c|}
\hline \multirow{2}{*}{ Duration of the surgery (Min) } & \multicolumn{2}{|c|}{ Appendicectomy } & \multicolumn{2}{c|}{ *Significance } \\
\cline { 2 - 3 } & Open & Laparoscopy & ' $\mathrm{t}$ ' & 'p' \\
\hline Mean duration /SD & $53.8 \pm 20.4$ & $71.2 \pm 19.23$ & \multirow{2}{*}{3.16} & 0.01 \\
\hline Maximum time & 100 & 120 & & \\
\hline Minimum time & 20 & 15 & & \\
\hline
\end{tabular}

In present study, the mean duration of surgery was $(53.8 \pm 20.4) \mathrm{min}$ in the open group and $(71.2 \pm 19.23) \mathrm{min}$ in the laparoscopy group. This difference was statistically significant $(\mathrm{P}<0.01)$.

Figure-37: Duration of the surgery

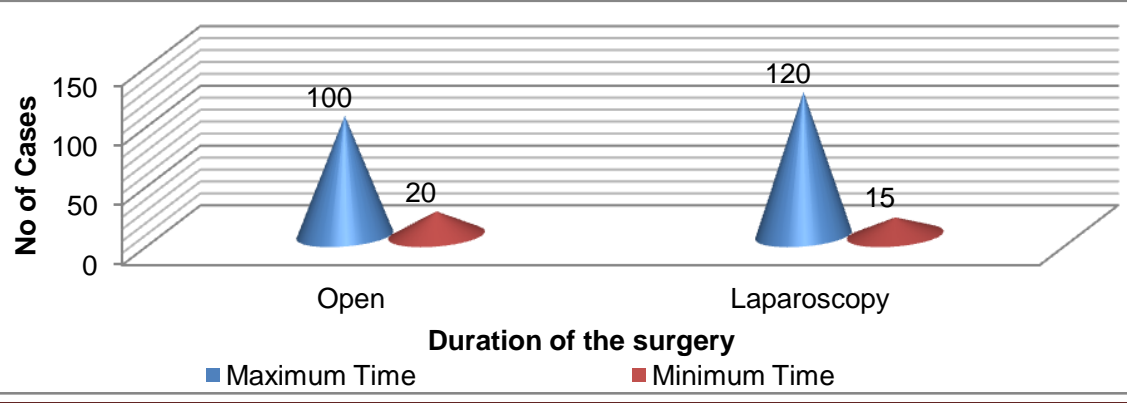




\section{JMSCR Vol||05||Issue||01||Page 15795-15808||January}

Tabl-8 : Post operative pain score and medication

\begin{tabular}{|l|c|c|c|c|}
\multirow{2}{*}{ Details } & \multicolumn{2}{|c|}{ Appendicectomy } & \multicolumn{2}{c|}{ *Significance } \\
\cline { 2 - 5 } & Open Mean SD & Laparoscopy Mean SD & ' $\mathrm{t}$ ' $\mathrm{p}$ ' \\
\hline Pain score (0-4) at the end of 24 hrs & $2.72 \pm 0.87$ & $1.21 \pm 0.63$ & 7.19 & 0.001 \\
\hline Duration of Analgesics used Parenteral and oral (days) & $6.44 \pm 1.84$ & $2.2 \pm 1.08$ & 9.86 & 0.001 \\
\hline
\end{tabular}

In present study, mean pain score was $(2.7 \pm 0.87)$ in open group as compared to $(1.21 \pm 0.63)$ in laparoscopic group with $\mathrm{P}<0.001$ which was significant. The mean duration of analgesics used parenteral and oral in days were on an average $(6.44 \pm 1.84)$ and $(2.2 \pm 1.08)$ for open and laparoscopic group respectively. Again this difference was significant $(\mathrm{P}<0.001)$.

Above analysis reveal that both pain and duration of analgesics used were highly significantly reduced in laparoscopic compared to open appendicectomy.

Figure-38: Post operative pain score and medication

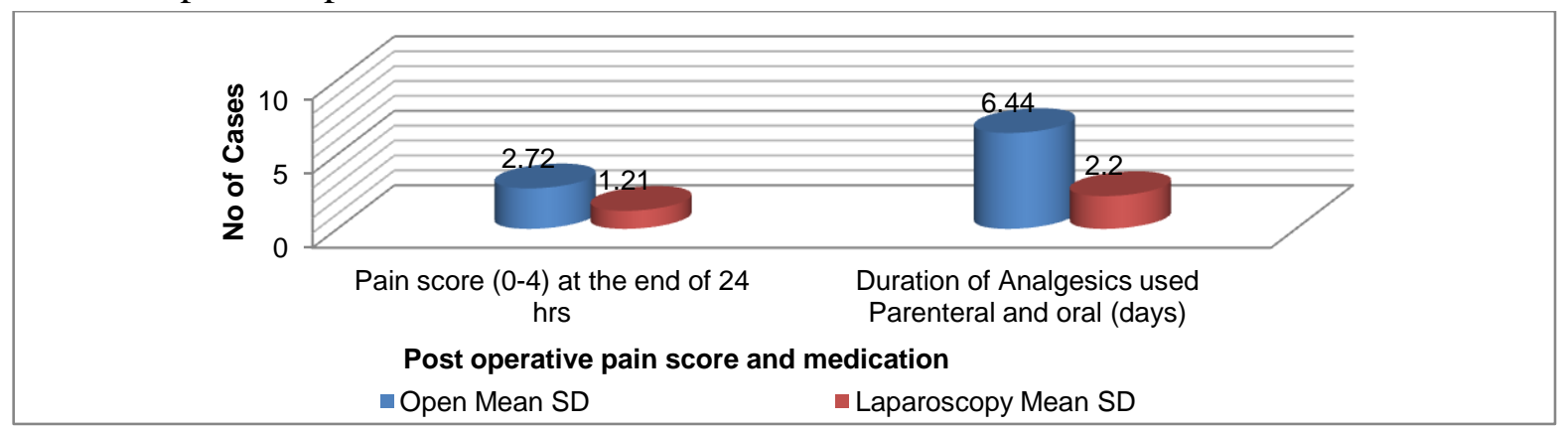

Table-9 : Postoperative Complications

\begin{tabular}{|c|c|c|c|c|c|c|}
\hline \multirow[t]{3}{*}{ Complication } & \multicolumn{4}{|c|}{ Appendicectomy } & \multicolumn{2}{|c|}{ *Significance } \\
\hline & \multicolumn{2}{|c|}{ Open } & \multicolumn{2}{|c|}{ Laparoscopy } & \multirow[t]{2}{*}{ 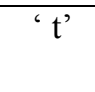 } & \multirow[t]{2}{*}{ 'p' } \\
\hline & $\mathrm{N}$ & $\%$ & $\mathrm{~N}$ & $\%$ & & \\
\hline Vomiting & 7 & 28 & 2 & 8 & \multirow[t]{4}{*}{12.12} & \multirow[t]{4}{*}{0.01} \\
\hline Fever & 4 & 16 & 1 & 4 & & \\
\hline Wound Infection & 5 & 20 & 1 & 4 & & \\
\hline Ileus in hrs & \multicolumn{2}{|c|}{$30.8 \pm 8.9$} & \multicolumn{2}{|c|}{$17.3 \pm 7.1$} & & \\
\hline
\end{tabular}

In present study post operative complications were analyzed in detail: vomiting, fever, wound infection and ileus.

The incidence of vomiting 7 (28\%) was higher following open appendicectomy than laparoscopic group 2(8\%).

Average post operative ileus was (30.8 \pm 8.9)hours for open and $(17.3 \pm 7.1)$ hours for laparoscopic group was noted .

Figure 39 : Postoperative Complications

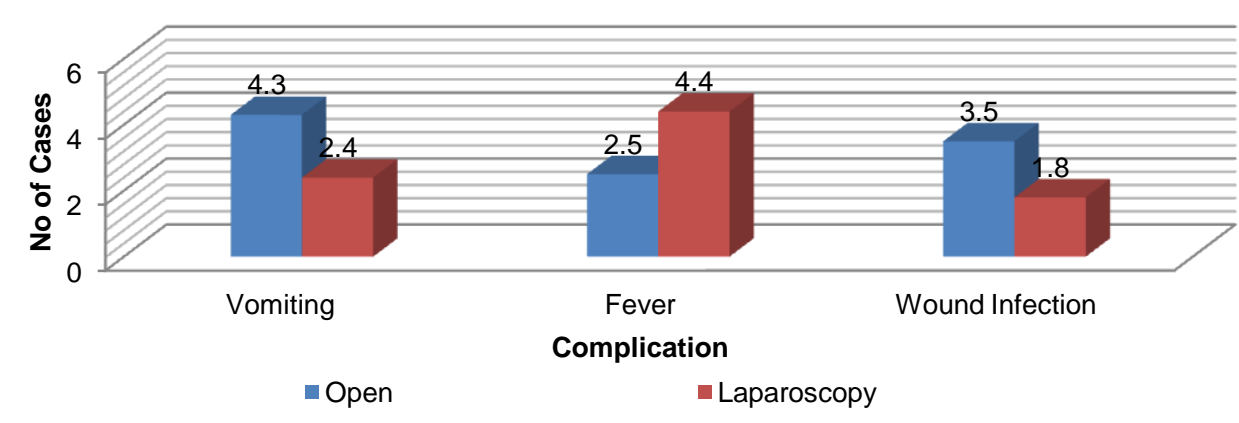

$5(20 \%)$ than laparoscopic group $1(4 \%)$.

Fever4(16\%)developed more in the open group than the laparoscopic group1 (4\%).

All these parameters where significant with $\mathrm{P}$ $<0.01$ 


\section{JMSCR Vol||05||Issue||01||Page 15795-15808||January}

Table -10 : Post operative Recovery

\begin{tabular}{|l|c|c|c|c|}
\hline \multirow{2}{*}{ Details } & \multicolumn{2}{|c|}{ Appendicectomy } & \multicolumn{2}{|c|}{ *Significance } \\
\cline { 2 - 5 } & Open Mean /SD & Laparoscopy Mean /SD & 't' & 'p' \\
\hline Duration of hospital stay after surgery (days) & $7.7 \pm 1.95$ & $2.8 \pm 1.23$ & 4.9 & 0.001 \\
\hline Time taken for return to normal work (days) & $20.8 \pm 3.21$ & $13.5 \pm 2.86$ & 7.3 & 0.001 \\
\hline
\end{tabular}

Mean Duration of post operative hospital stay for open group $(7.7 \pm 1.95)$ and $(2.8 \pm 1.23)$ days for laparoscopic group. Which shows that laparoscopic appendicectomy significantly reduced the hospital stay $(\mathrm{P}<0.001)$.
Patients who had laparoscopic appendicectomy return to full activities was (13.5 \pm 2.86$)$ versus( $20.8 \pm 3.21)$ days for patients who underwent open appendicectomy. Again this difference was significant $(\mathrm{P}<0.00)$.

Figure-40: Post operative Recovery

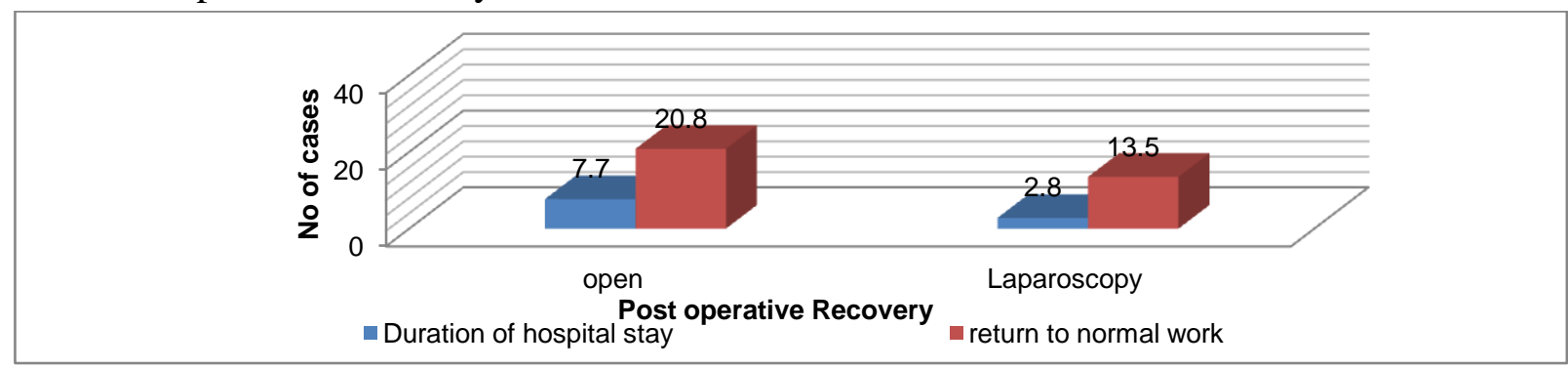

\section{Discussion}

The pendulum of the surgical opinion continuous to swing with gradual decreasing sweep as the appropriate application of the laparoscopy for the suspected case of the acute and recurrent appendicitis is popularizing.

Critics of laparoscopic appendicectomy often point to the increase cost of the surgical equipments as a major disadvantages of the laparoscopic procedure despite these concerns, it has become safe popular procedure. However the cost effectiveness for laparoscopic appendicectomy is easily realized once the decreased hospital stay and entire patient convalescence period are accounted for laparoscopy as a major surgical advantage has enable the general surgeon to stretch his hands in the Superspeciality area. The controversy that currently exits over the potential benefit of laparoscopic appendicectomy motivated us to analyze our experience with this procedure.

The relative advantage and disadvantages of the laparoscopic and open appendicectomy are measured primarily in terms of duration of surgery, post operative pain score and duration of analgesic used in days, Post operative complication like ileus ,fever, vomiting, wound infection post operative recovery in the terms of post operative duration of hospital stay, returns to normal were assessed.

In this study the mean age group is $27.2 \mathrm{yrs}$ and $25.5 \mathrm{yrs}$ in the open and laparoscopic group respectively.

Table-11: Duration of surgery

\begin{tabular}{|l|c|c|}
\hline & Mean time (minutes) & \\
\hline Studies & Open & Laparoscopy \\
\hline Heikkim T.J et al & 82 & 91 \\
\hline Ortega AE et al & 58 & 68 \\
\hline Youg JL et al & 60 & 80 \\
\hline Geeta.K.R et al & 58.2 & 74.13 \\
\hline Present study & 53.8 & 71.2 \\
\hline
\end{tabular}

In our study there was significant increases in the mean time taken for the procedure during laparoscopic appendicectomy compared to the open method (LA $71.2 \pm 19.2$ Vs. OA $53.8 \pm$ 20.04) respectively. This was statistically significant $(\mathrm{P}<0.01)$ Similar Studies were observed in some of the studies $21,27,38,42$. 


\section{JMSCR Vol||05||Issue||01||Page 15795-15808||January}

This was because of learning curve level of surgical experience and patient selection accounted for increased operative time.

Table-12: Post operative pain score at the end of 24 hours

\begin{tabular}{|l|c|c|}
\hline & $\begin{array}{c}\text { Pain score (0-4) } \\
\text { (Mean) }\end{array}$ & \\
\hline Studies & Open & Laparoscopy \\
\hline Ortega AE et al & 3.25 & 2.01 \\
\hline $\begin{array}{l}\text { Swneeny KJ et } \\
\text { al }\end{array}$ & 3.01 & 2.25 \\
\hline Present study & 2.72 & 1.21 \\
\hline
\end{tabular}

In our study there was significant difference in the mean post operative pain score between open and laparoscopic appendicectomy at the end of $24 \mathrm{hrs}$ $(\mathrm{OA}, \quad 2.72 \pm 0.87$ Vs LA, $1.21 \pm 0.63)$ respectively; $\mathrm{p}<0.001)$. Similar observation has been reported by others 27,30 ,

This difference is because of a longer incision and stretch of the muscles

Table-13: Post operative analgesic used parenteral and oral (days)

\begin{tabular}{|l|c|c|}
\hline & $\begin{array}{c}\text { Number of days } \\
\text { (Mean) }\end{array}$ & \\
\hline Studies & Open & Laparoscopy \\
\hline Frazee RC et al & 6.95 & 2.29 \\
\hline Shaikh AR et al & 7.25 & 3.95 \\
\hline Geeta.K.R et al & 7.05 & 3.31 \\
\hline Present study & 6.44 & 2.20 \\
\hline
\end{tabular}

In our study mean duration post operative analgesic parenteral and oral doses required in days was more in the open group than the laparoscopic group (OA, 6.44 \pm 1.84 Vs. LA, 2.2 \pm 1.08 ) respectively: $p<0.001$. Similar observation has been reported by others. ${ }^{27,40.42}$.

Table-14: Duration of hospital in days

\begin{tabular}{|l|c|c|}
\hline & $\begin{array}{c}\text { Number of days } \\
\text { (Mean) }\end{array}$ & \\
\hline Studies & Open & Laparoscopy \\
\hline Attwood SE et al & 3.8 & 2.5 \\
\hline Yong JL et al & 4 & 3 \\
\hline Wei HB Hung et al & 7.2 & 4.1 \\
\hline Geeta.K.R et al & 4.36 & 3.31 \\
\hline Present study & 7.7 & 2.8 \\
\hline
\end{tabular}

In our study mean duration of hospital stay was significantly lower for the Laparoscopic group $(2.8 \pm 1.73)$ days as compared to the open group $(7.7 \pm 1.95)$ with $(\mathrm{P}<0.001)$

Similar studies has been reported by others $^{19,38,39,42}$.

Post operative complication like, vomiting was lower in laparoscopic groups $2(8 \%)$ as compared with $7(28 \%)$ in open group and fever was lower in laparoscopic group $4(16 \%)$ as compared with 1 $(4 \%)$ in open group.

Table-15: Post operative wound infection

\begin{tabular}{|l|c|c|}
\hline & $\begin{array}{c}\text { Number of cases } \\
\text { (Mean) }\end{array}$ & \\
\hline Studies & Open & Laparoscopy \\
\hline Ortega AE et al & 11 & 4 \\
\hline Geeta.K.R et al & 11 & 0 \\
\hline Present study & 5 & 1 \\
\hline
\end{tabular}

In our study mean post operative wound infection rate was lesser in laparoscopic group with 1(4\%), as compared with $5(20 \%)$ in open method. The similar observation has been observed. ${ }^{27,42}$. All these parameters were significant with $\mathrm{P}<0.01$.

Table-16: Post operative ileus in hours

\begin{tabular}{|l|c|c|}
\hline & $\begin{array}{c}\text { Number of } \\
\text { hours (Mean) }\end{array}$ & \\
\hline Studies & Open & Laparoscopy \\
\hline Swneeny KJ et al & 33.3 & 20.6 \\
\hline Yasmin Vellani et al & 21.0 & 10.6 \\
\hline Present study & 30.8 & 17.3 \\
\hline
\end{tabular}

In our study mean post operative ileus was lower in laparoscopic group with $(17.3 \pm 7.1 \mathrm{hrs})$ and for open group $(30.8 \pm 8.9 \mathrm{hrs})$. The similar studies have been observed ${ }^{30,41 \text {. }}$

Table-17: Return to normal work (days)

\begin{tabular}{|l|c|c|}
\hline & $\begin{array}{c}\text { Number of days } \\
\text { (Mean) }\end{array}$ & \\
\hline Studies & Open & Laparoscopy \\
\hline Ortega AE et al & 14.0 & 9.0 \\
\hline Pedersen AG et al & 26.5 & 14.0 \\
\hline Wei HB Hung et al & 13.7 & 9.1 \\
\hline Geeta.K.R et al & 19.44 & 13.86 \\
\hline Present study & 20.8 & 13.5 \\
\hline
\end{tabular}


In out studies return to normal work was earlier for the laparoscopic group (13.5 \pm 2.86 days) as compared to the open appendicectomy $(20.8+$ 3.21 days). This difference being Significant $(\mathrm{P}<0.001)$. Other studies has also shown similar result. $^{27,29,39,42 .}$

In addition to a therapeutic modality laparoscopic has distinctive advantage of being a diagnostic tool.

There was no case of conversion from laparoscopic appendicectomy to open appendicectomy in our study.

\section{Conclusion}

On analyzing the data, we found a definite difference in outcome between open and laparoscopic appendicectomy in a properly selected patient. The laparoscopic appendicectomy was better than the open appendicectomy with respect to:

- Post operative pain.

- Duration of analgesic use.

- Postoperative complications like vomiting, ileus, fever, and wound infection,

- Post operative length of hospital stay.

- Return to normal work.

Overall, laparoscopic appendicectomy is better than open appendicectomy in selected patients with acute or recurrent appendicitis, at a cost of slight increase in duration of surgery.

\section{Summary}

Appendicitis is the most common intra abdominal condition requiring emergency surgery; appendicectomy is the commonest procedure in general surgery. Although a number of trials have analyzed the outcome of laparoscopic versus open appendicectomy the value of laparoscopy in appendicitis is not established.

Krishna Institute of Medical Sciences, Karad. with a clinical diagnosis of acute or recurrent appendicitis from Oct 2014 to June 2016 (including sampling procedures, if any).

This study was done from Oct 2014 to June 2016 on 50 patients with clinical diagnosis of acute or recurrent appendicitis admitted in surgical wards of Krishna Institute of Medical Sciences, Karad. The patients were selected by random sampling technique. All the patients were followed every day in post operative period till they were discharged and then later followed for a period of 4 weeks in and out patients department .The following parameters were observed during follow up in comparison between two procedure with, duration of surgery, post operative pain and duration of analgesics used, post operative complication, hospital stay and return to normal activities.

After analyzing the data using chi- square test and students $t$ test we noticed that, there are significant difference between the two procedure with laparoscopic appendicectomy being better in respect to postoperative pain. (LA, $1.21 \pm 0.63 \mathrm{Vs}$. OA, 2.72 \pm 0.87 : $\mathrm{P}<0.001)$ duration of analgesic used (LA, $1.21 \pm 0.63$ Vs. OA, 2.72 \pm 0.87 : $\mathrm{P}<0.001)$ duration of analgesic used (LA,2.2 \pm 1.08 Vs. OA, $6.44 \pm 1.84: \mathrm{P}<0.001)$ postoperative complications like vomiting [LA, $2(8 \%)$ Vs. O.A, 7 (28\%), fever [LA, 1 (4\%) Vs. OA, 4 (16\%), wound infection [LA, 1 (4\% Vs. OA, 5 (20\%), ileus (LA, $17.3 \pm 7.1$ Vs. OA, 30.8 $\pm 8.9: \mathrm{P}<0.001$ ) postoperative length of hospital stay (LA,2.8 \pm 1.23 Vs.OA, 7.7 $\pm 1.95: \mathrm{P}<0.001)$ and return to normal work (LA, 13.5 \pm 2.86 Vs.OA, $20.8 \pm 3.21: \mathrm{P}<0.01$ ). Although above mentioned advantage were at the cost of slightly increased duration of surgery (LA,71.2 \pm 19.23 Vs.OA,53.8 $\pm 20.04: \mathrm{P}<0.01$ ).

We conclude that the laparoscopic appendicectomy is better than open method for acute or recurrent appendicitis, with less postoperative pain and reduced duration of analgesic used, with lesser incidences of postoperative complication, shorter duration of hospital stay and early return to normal work with the cost of slight increase in duration of surgery.

\section{Bibliography}

1. Hamilton bailey's "Emergency Surgeries" $12^{\text {th }}$ Edition .., 1995; 438-451. 
2. Liuco, Mcfudden DW, "Acute abdomen and appendix", In, Gramfield I J et al, eds surgery: scientific Principle and pratices $2^{\text {nd }}$ edition.

3. Jaffe Bm Anel Berger DH, "The appendix" "Chapter 30 in Scnwartz's principle of surgery" Bruniardi F, Anderson DK, Biliar TR, DUNNDL, Hunter JG, Pollock RE, Eds, $9^{\text {th }}$ Edn , Mcgraw- Hill medical publishing division New York, 2005, 1075-1092.

4. Palanivelu "Laparoscopic appendicectomy" chapter 53 in text book of surgical laparoscopy, Shrinivas Fine art limited 2002: 411- 424.

5. John Morgan, Cosgrove and Geroge Gallos. "Laparoscopic Appendicectomy", chapter, 5, 54, minimally invasive surgery, David brookes springer.

6. Britton J, Barr H "Endoscopic Surgery. Chapter 13 in oxford text book of surgery, Morris PS, Malt RA. Eds Vol.1, $2^{\text {nd }}$ Edn, oxford Medical Publications, 1994; 847862.

7. Willams NS, Bulstrode CJK, O' Connel PR. "The vermiform appendix", chapter 67 in Short practice of surgery, bailey and Love's $25^{\text {th }}$ Edn, Arnold publication 2008; 1204-1218.

8. Apelgren $\mathrm{KN}$, Cowan BND, Metcalf ANM, carol EH, "Laparoscopic appendicetomy and the management of gyenecologic pathologic condition found at laparoscopy for presumed appendicitis", in Surgical Clinics of North America, June 1996; 76:469-482.

9. Eubanks s' Schaver PR “ Laproscopic surgery" chapter 27 in textbook of surgery, $15^{\text {th }}$ Edn, Suabiston DC, Kirn H, layer Edn W.B Saunder's company Prism Books (Pvt) Ltd. 1997; 791-807.

10. Willams, G.R., 1983, “A history of appendicitis” Ann. Surg., 197:495f.
11. Kelly; H.A. and Hurton. E., 1905. "The vermiform Appendix" and its diseases. W.B.Saunders, Philadelphia.

12. Shepherd. J.A., 1960, Surgery of Acute abdomen, E. and S. Livingston Ltd. P. 410.

13. Seal. A., 1981, "Appendicitis: a historical review”. Canadian J.of Surg., 24 (4): 427

14. Ellish, Nalranson LK, "Appendix and Appendicectomy", chapter 39 in Maingots Abdomonal "Zennee MJ, Schwartz SI, Ellish, Ashley SW, Mc fadden OW, Eds, Vol.2,10 Edt. A Simon and Schuster compangusm1997: 1191-1227.

15. Fitz R.H. perforating inflammation of "Vermiform Appendix" with special reference to its early diagnosis and treatment, trans arsac Am Physicians, 1886; 1: 107.

16. McBurney c, "Experience with early operative interference in case of disease of the vermiform appendix". New York Medical Journal 1889, 1: 676-684.

17. Semm K. "Endoscopic appendicectomy", Endoscopy 1983; 15:59-64.

18. Pier A, Gotz F, Bacher C. "Laparscopic appendicectomy in 625 cases: from innovation to routine", Surg laprscopy endosc, 1991; 1(1): 8-13.

19. Attwood SE, hill AD, Murphy PG, Surgery 1992 Sept 112 (3); 497-501.

20. Gurtaz AT, Peetz M.E, "The acute abdomen in Pregant patients. Its there a role of Laprscopy" Sury Endoscopy; 11: 98-102, 1997.

21. Heikkim T.J et al, "Cost Effective appendicectomy open or Laparoscopic?" Surg Endoscopy 1998, Oct 12(10); 1204-8.

22. McAnena OJ, Austin O, OConnell PR, Hederman WP, Gorey TF, Fitzpatrick J. "Laparoscopic versus open appendicectomy: A Prospective evaluation" $\mathrm{Br} \mathrm{J}$ Surg 1992; 79:818-820

23. Valina VL, Velasco JM, McCulloch CS. "Laparoscopic versus conventional 
appendicectomy", Ann Surg 1993; 218: 685-692

24. Tata JJT, Chung SCS, Dawson J, Leong HT, Chan A, Lau WY, et al. "Coventional versus laparoscopic Surgery for acute appendicitis". Br J Surg june 1993; 80:761-762.

25. Bennett J, Boddy A, Rhodes M, Choice of approach for appendicectomy: A metaanalysis of open versus laparoscopic appendicectomy. Surg laparosc Endosc Percutan Tech 2007; 17: 245-255.

26. Frazee RC, Robert JW, Symmonds RE, Snyder SK, Hendricks JC, smith RW et al. A prospective randomized trial comparing open versus laparscopic appendectomy. Ann Surg 1994; 219: 725-731.

27. Ortega AE, John Hunter G, Jeffrey Peters H, Lee Swanstrom L, Bruce Schirmer. "A Prospective randomized comparison of laparoscopic appendicectomy with open appendicecetomy". Am J of Surg 1995; 169; 208-213.

28. Chung RS, Rowland DY, Paul Li, Diaz J. "Meta- analysis of randomized controlled trial of laparoscopic versus conventional appendectomy". Am J Surg 1999; 177: 250-256.

29. Pedersen AG, Petersen OB, Wara P, Ronning H, Qvist N, Laurberg S. "Randomised Clinical trial of laparoscopic versus open appendicectomy". Br of Surg 2001; 88, 200-205.

30. Swneeny KJ, Keane FBV. "Moving from open to laparoscopic appendicectomy". $\mathrm{Br}$ J of Surg 2003; 90: 257-258.

31. Guller U, Hervey S, Purves H, Muhlbaier LH, Peterson ED, Eubanks S, et al. "Laparoscopic versus open appendicectomy outcomes comparison based on a large administrative database". Ann Surg 2004; 239: 43-52.

32. Josloff RK, Zucker KA, Eds.,"Laparoscopic appendectomy" chapter 19 ,in surgical laparoscopy, $2^{\text {nd }}$
Edn, Lippincott Williams and Wilkins Publication 2001; 229-235.

33. Tucker JG, Ramshaw BJ," Laparoscopic appendicectomy" in Mastery of endoscopic and laparoscopic surgery, Eubanks WS, Swanstorm LL, Soper NJ, EDS,. Lippincott Williams and Wilikins Publication, 2000; 355-363.

34. Kazemier G., G. R. de Zeeuw, Lange JF., hop W.C.J., Bonjer H.J "Laparscopic versus open appendicectomy: A randomized Clinical trial". Surg Endosc 1997 11: 336-340.

35. Laine S Cantal A et al; "Laparoscopic appendicectomy" is it worth while Surg Endosc, Vol.11, 1997, page 95-97.

36. "Laparoscopic Vs open Appendicectomy" in West Bengal, India, Chewre Journal of Digestive Diseases, Vol6 Number 4, November 2005; 169(5): 165-169.

37. "Value of laparoscopic appendicectomy" in performat appendicectomy and world Journal Surgery. Jan 2007; 31 (1): 93-97.

38. Yong JL, Law WL, Lo CY, Lam CM. “A comparative study of routine laparoscopic versus open appendectomy". Department of Surgery, University of Hong Kong Medical Centre, Queen Mary Hospital, Hong Kong, China. JSLS. 2006 AprJun;10(2):188-92.

39. Wei HB, Huang JL, Zheng ZH, Wei B, Zheng F, Qiu WS, Guo WP, Chen TF, Wang TB. "Laparoscopic versus open appendectomy": a prospective randomized comparison." Department of Gastrointestinal Surgery, The Third Affiliated Hospital of Sun Yat-Sen University, GuangZhou, China. Surg Endosc. 2010 Feb;24(2):266-9. Epub 2009 Jun 11.

40. Shaikh AR, Sangrasi AK, Shaikh GA. "Clinical outcomes of laparoscopic versus open appendectomy". Liaquat University of Medical \& Health Sciences Jamshoro, 
Sindh, Pakistan. JSLS. 2009 OctDec;13(4):574-80.

41. Yasmin Vellani,Shaheena Bhatti, Ghina Shamsi "''Evaluation of Laparoscopic Appendectomy vs. Open Appendectomy: A Retrospective Study" at Aga Khan University Hospital, Karachi, Pakistan :JSLC:2009.oct-dec 13(4):574-80

42. Geeta.K.R .Annappa Kudva. Bhavatej: "Laparoscopic appendicectomy versus open appendicectomy: A comparative study of clinical outcome and cost analysis -Institutional experience”. Indian J Surg (May-June 2009)71:142-146

43. Sadler TW, "Digestive system" chapter 13 in Langman's Medical Embryology, $9^{\text {th }}$ Edn, Lippincott Williams and Wilikins publications 2004; 307-308.

44. "Large bowel, Anal canal and Ischiorectal fossa", chapter 5, in Le McGregor's synopsis of surgical anatomy, Decker GAG and Du Plessis DJ., Eds., $12^{\text {th }}$ Edn, Varghese Publishing house, Bombay, 1995; 41.

45. 'Vermiform appendix", chapter 78, in Gray's Anatomy,Susan standarding Eds.,39 ${ }^{\text {th }}$ Edn Churchill livingstone, London, $2005: 1189-1190$

46. Somen Das. "The Vermiform Appendix" chapter 52; in A concise text book of surgery. 4th Edition -2006 page -10221034.

47. Lally KP, Cox SC and Andrassy RJ," The appendix", chapter 49, in sabiston text book of Surgery, Townsend CM, Beauchamp RD, Evers BM, mattox KL, Eds., $18^{\text {th }}$ Edn., Vol 2, Elsevier India Private Limited New Delhi, 2005; 1333-1347.

48. E, lawrance, keys (Surgical Clinical of North American), Oct 1967; 1447-1456.

49. Boyd w. Pathology of surgeons 1996; $8^{\text {th }}$ Edition (Philadilphia W.B.Saunders).

50. Cope. Z.A history of acute abdomen (England oxford University Press, 1965; London)
51. Bhajekal , M.V Surgical Appendix (Indian Journal of Medical Science; 1963 Bombay).

52. Kenneth S. Latchns; American Journal of Surgery, 1966; 111; 220.

53. De SN and Sengupta K.P ; Journal of Indian Medical Association 1952; 21-243.

54. Kileman.E. "Physical Diagnosis of acute abdominal disease and injuries" (Budapest; Academia kiado 1964).

55. Hamilton's Bailey's Demonstration of physical Signs in Clinical Surgery by Allon Clain $-18^{\text {th }}$ Editions.

56. Somen Das; "Examination of acute abdomenly "chapter-33; A manual of Clinical Surgery $8^{\text {th }}$ Edition- page-433-456.

57. Field S, Morrison L, "The acute Abdomen", chapter 22 in text book of Radiology and imaging, David Sutton, Edn., $\quad 7^{\text {th }}$ Edn., Vol.1 Churchill Livingstone. London, 1998; 683-685.

58. Ferguson SM," Acute Appendicitis" chapter 27.1, in Shackelford's Surgery of the Alimentary tract, Zuidema GD., Yeo CJ., Femberton J., Eds., $5^{\text {th }}$ Edn., Vol 4, W.B.Saunders Company USA, 1995; 1539-1543.

59. "Classic Operations on the small and large bowel", chapter 21 in Farquharson's textbook of Operative general Surgery, Farquharson's M., Brenden M., Eds., $9^{\text {th }}$ Edn., Hodder Arnold, 2005; 379-382.

60. Jorbee Banee et al. "Antibiotic prophylaxis in acute non perforate appendicectomy the Danis multricentric study group III": (Ann Surgery: 1989; 209; 3)

61. Dudely HAF: Hamelton Barley's Emergency Surgery $11^{\text {th }}$ Edition 1986.

62. Lasley P.F, “Techniques of laparoscopic Appendicectomy" (Surgical work shop, Journal of Surgery; 76:8, 7740-79).

63. Michael LB., Soper NJ., "Laparoscopic Surgery", chapter 4 in Maingot's Abdominal Operations", Zinner MJ., Ellis H., Schwartz SI., Ashley SW., Eds., Vol.2, 
$10^{\text {th }}$ Edn., A Simon and Schuster Company USA. 1997; 251-252.

64. Caushaj PF., "Laparoscopic Appendicectomy", chapter 25, in Atlas of Laparoscopic Surgery, ballantyne GH., Eds., W.B.Saunders company, 2000; 300-307.

65. "Appendicectomy", chapter 7 in Advance Laparoscopic Surgery, Techniques and Tips,Namir Katkhouda N., Eds., W.B. Saunders Company Eastern press, 2001; 106-107. 